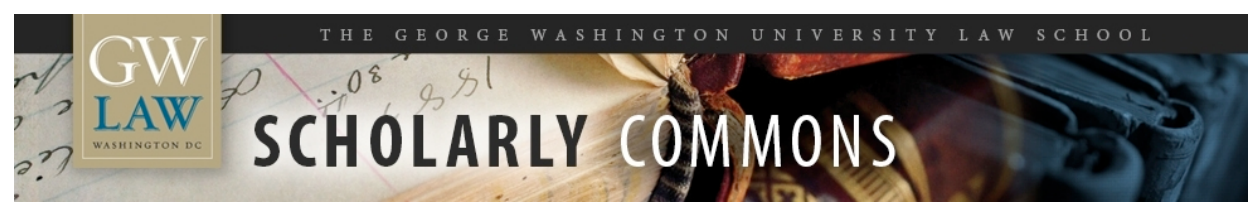

\title{
The Inherent Limits of Judicial Control of Agency Discretion: The D.C. Circuit and the Nondelegation Doctrine
}

Richard J. Pierce Jr

George Washington University Law School, rpierce@law.gwu.edu

Follow this and additional works at: https://scholarship.law.gwu.edu/faculty_publications

Part of the Law Commons

\section{Recommended Citation}

Richard J. Pierce Jr., The Inherent Limits of Judicial Control of Agency Discretion: The D.C. Circuit and the Nondelegation Doctrine, Admin. L. Rev. (2000).

This Article is brought to you for free and open access by the Faculty Scholarship at Scholarly Commons. It has been accepted for inclusion in GW Law Faculty Publications \& Other Works by an authorized administrator of Scholarly Commons. For more information, please contact spagel@law.gwu.edu. 
revised August 31

THE INHERENT LIMITS ON JUDICIAL CONTROL OF AGENCY DISCRETION: THE D.C. CIRCUIT AND THE NONDELEGATION DOCTRINE

\author{
Richard J. Pierce, Jr.
}

In American Trucking Associations v. EPA (ATA), ${ }^{1}$ the D.C. Circuit shocked the world of administrative law by holding that the most important provision of the Clean Air Act (CAA) is unconstitutional as interpreted and applied by the Environmental Protection Agency (EPA).

Specifically, a two-judge majority of a panel held that EPA's construction of section 109(b) of the CAA violates the nondelegation doctrine because EPA "offers no intelligible principle" that can be used to determine the level at which a primary ambient air standard should be set. ${ }^{2}$ The court further held that EPA cannot apply section 109(b) unless and until it develops and adopts "determinate, binding standards" that EPA and reviewing courts can apply to determine the proper level for a primary air standard..$^{3}$ The holding in ATA may be short-lived. It is a good candidate for reversal either by the en banc circuit or by the Supreme Court. The issues the ATA court addresses are hardy perrennials, however, that are worthy of serious analysis independent of the specifics of the case.

I have three goals in this essay. First, I will argue that all three of the judges who comprised the

* Lyle T. Alverson Professor of Law, George Washington University. I am grateful to Lisa Heinzerling, Tom Sargentich, and the participants in the George Washington works-in-process group for making many helpful suggestions on an earlier version of this essay.

1 175 F. 3d 1027 (D.C. Cir. 1999).

2 Id. at 1036-1037. This holding is in part I of the opinion. The court addressed several other issues in parts II, III, and IV. I address only part I of the opinion.

3 Id. at 1038. 
panel succumbed to, and contributed to, what Wendy Wagner calls the "science charade" -demanding more of science, and finding more in science, than science can deliver. ${ }^{4}$ Any decisionmaking standard that purports to be significantly more "determinate" and "binding" than the standard EPA applied would be a fraud. Second, I will argue that the remedy adopted by the D.C. Circuit is profoundly antidemocratic. It would either empower judges to make a major policy decision or empower a President to make a major policy decision that binds his successors, thereby severely limiting the power of the people to influence policymaking by voting in Presidential elections. Third, I will argue that the degree of indeterminacy that the court found fatal in EPA's construction of CAA section 109(b) poses no threat to our constitutional structure or values. It is instead symptomatic of a basic characteristic of our political system -- Presidential elections matter.

In part I, I provide a descriptive overview of the two rulemakings that the court reviewed. In part II, I describe the majority and dissenting opinions in ATA. In part III, I explain the different ways in which the majority and dissenting opinions fell prey to, and contributed to, the science charade. In part IV, I explain why the goals of the majority are unattainable through use of any plausible decisionmaking standard. In part V, I explain why the remedy imposed by the court conflicts with our most fundamental constitutional value -- major policy decisions should be made by institutions that are accountable to the people. In part VI, I explain why I am not at all uncomfortable with the legal regime the ATA court found to be fatally flawed. That legal regime allows the people to influence agency policymaking by voting in Presidential elections.

${ }^{4}$ Wendy Wagner, The Science Charade in Toxic Risk Regulation, 95 Colum. L. Rev. 1613 (1995). 


\section{THE RULEMAKINGS}

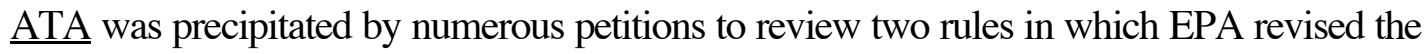
primary and secondary national ambient air quality standards applicable to ozone and particulate matter. In the particulate rulemaking, EPA increased the stringency of the annual and 24-hour primary standards and added new standards applicable to smaller particles. ${ }^{5}$ There were hundreds of controverted issues in the particulate rulemaking. The controversy over competing levels of tolerance of periods in which particulate concentrations exceed the 24-hour standard illustrates the typical controversy. Most public health authorities urged EPA to adopt a 99th percentile measure, while most industry commentators urged EPA to adopt a 95th percentile measure. ${ }^{6}$ EPA adopted a 99th percentile measure. $^{7}$ In the ozone rulemaking, EPA increased the stringency of the primary ozone standard from $0.12 \mathrm{ppm}$ to $0.08 \mathrm{ppm}$ and made several changes in the form of the standard. ${ }^{8}$ There were hundreds of controverted issues in the ozone rulemaking, but much of the controversy focused on the appropriate level of the eight-hour primary ozone standard. Many industry groups urged EPA to adopt a 0.09 ppm standard, while most environmental groups urged EPA to adopt a 0.07 ppm

5 National Ambient Air Quality Standards for Particulate Matter, 62 Fed. Reg. 38652 (July 18, 1997).

${ }^{6}$ Id. at 38678.

${ }^{7}$ Id. at 38678.

8 National Ambient Air Quality Standards for Ozone, 62 Fed. Reg. 38856 (July 18, 1997). 
standard. ${ }^{9}$ EPA adopted a 0.08 standard. ${ }^{10}$

A few general characteristics of the rulemakings will help to put the issues in context. EPA considered over one hundred recent studies of the relationship between particulates, ozone, and human health. ${ }^{11}$ It received over 100,000 comments on its proposals and on the studies that were the basis for its proposals. ${ }^{12}$ EPA devoted thousands of pages to the process of discussing the studies, the comments, and its reasons for making each decision in the standard-making process. ${ }^{13}$

\section{THE JUDICIAL OPINIONS}

The ATA majority began by describing the applicable statutory regime. For each of 130 criteria pollutants, CAA section 109(b) requires EPA to set a "primary standard" "requisite to protect the public health" with an "adequate margin of safety."14 The D.C. Circuit had previously interpreted section 109(b) to authorize EPA to consider only human health, and to forbid it from considering feasibility or cost, in setting primary standards. ${ }^{15}$

9 Id. at 38870 .

10 Id. at 38868 .

11 The new studies EPA considered are listed at 62 Fed. Reg. 38709-38711, 38894.

1262 Fed. Reg. 38654, 38858.

13 The statements of basis and purpose occupy 244 pages of the Federal Register and incorporate by reference the lengthy analyses contained in the Notices of Proposed Rulemaking, the Criteria Documents, the Advisory Committee reports and recommendations, and the Staff Reports. 62 Fed. Reg. 38655, 38859.

$14 \quad 175$ F. 3d at 1032.

15 Id. at 1038. 
The majority then held that EPA's construction of section 109(b) violates the nondelegation doctrine. It is important to follow the majority's idiosyncratic reasoning with respect to the nondelegation doctrine and to understand what it did, and did not, hold to be unconstitutional. The majority did not hold that the language of section 109(b) violates the nondelegation doctrine. Such a holding would be indefensible in light of the many far less determinate statutory standards the Supreme Court has upheld -- "public interest,"16 "public convenience,"17 "fair and equitable,"18 and "just and reasonable."19 The majority also did not find fault in EPA's choice of decisionmaking criteria. EPA considers "severity of effect, certainty of effect, and size of population affected. ${ }^{120}$ The majority noted that these criteria were "long ago approved by the judiciary;" they "focus the inquiry on pollution's effects on public health;" and, they "pose no inherent nondelegation problem. ${ }^{121}$

The majority detected one fatal flaw in EPA's construction of the statute, however. According to the majority, "EPA lacks ... any determinate criterion for drawing lines. ${ }^{122}$ The majority illustrated this point by reference to EPA's explanation for its decision to set the ozone standard at $0.08 \mathrm{ppm}$,

16 National Broadcasting Co. v. U.S., 319 U.S. 190 (1943).

17 U.S. v. Southwestern Cable Co., 392 U.S. 157 (1968).

18 Yakus v. U.S., 321 U.S. 414 (1944).

19 FPC v. Hope Natural Gas Co., 320 U.S. 591 (1944). For a more complete discussion of the non-delegation doctrine, see Kenneth Davis \& Richard Pierce, I Administrative Law Treatise $\$ 2.6$ (3d ed.1994 and 1999 Supplement).

20175 F. 3d at 1035.

21 Id. at 1034-1035.

${ }^{22}$ Id. at 1034. 
instead of $0.09 \mathrm{ppm}$ or $0.07 \mathrm{ppm}$ :

EPA explains that its choice [of 0.08] is superior to . . $0.09 \mathrm{ppm}$, because more people are exposed to more serious effects at 0.09 than at 0.08 . . In defending the decision not to go down to 0.07 , EPA never contradicts the intuitive proposition, confirmed by data in its staff paper, that reducing the standard to that level would bring about comparable changes..$^{23}$

The majority then reasoned that EPA's construction violates the nondelegation doctrine by conferring on EPA impermissibly broad discretion to decide "how much is too much.'24 According to the majority, "EPA's formulation of its policy judgment leaves it free to pick any point between zero and a hair below the concentrations yielding London's Killer Fog. ${ }^{125}$

The majority then turned to the question of the appropriate remedy for EPA's unconstitutional statutory construction. The majority declined to hold that the statute itself is invalid, partly because such a holding is precluded by Supreme Court precedents, and partly because of the majority's belief that a constitutional construction of section 109(b) "is or may be available. ${ }^{126}$ Instead, it remanded the proceeding to EPA with instructions that EPA adopt "determinate, binding standards. ${ }^{127}$ The majority recognized that this remedy does not respond to a "key function of" the nondelegation doctrine -- to
${ }^{23}$ Id. at 1035 .
${ }^{24}$ Id. at 1034.
25 Id. at 1037.
26 Id. at 1038 .
27 Id. at 1038 . 
"ensure ... that important social policy choices are made by Congress .... ${ }^{128}$ The majority ascribed two other valuable functions to its remedy, however -- it will limit agency discretion, and it will provide a basis for judicial review of agency exercises of discretion. ${ }^{29}$ In order to serve those functions, it seems obvious that the construction must bind the agency for the indefinite future. The majority then suggested potential "determinate, binding standards" EPA might adopt on remand. ${ }^{30}$

The dissenting judge referred to the many circuit court decisions that have upheld and applied CAA section 109(b) and to the many Supreme Court decisions that have upheld delegations much less determinate than section 109(b). ${ }^{31}$ He also adopted a different interpretation of EPA's decisionmaking process. Like the majority, the dissent illustrated his point with reference to EPA's choice of $0.08 \mathrm{ppm}$, rather than 0.09 or 0.07 , as the eight-hour ozone standard. According to the dissenting judge, EPA based it choice of $0.08 \mathrm{ppm}$ not on differences in degrees of harm to human health but on differences in kinds of harm to human health. ${ }^{32}$

In the next section, I will argue that both opinions in $\underline{\text { ATA }}$ are symptomatic of what Wendy Wagner calls the science charade -- demanding more from science than it can deliver and finding more in science than is there. ${ }^{33}$ Before I begin that discussion, it is important to recognize the hyperbole in the

${ }^{28}$ Id. at 1038.

${ }^{29}$ Id. at 1038.

${ }^{30}$ Id. at $1038-1040$.

${ }^{31}$ Id. at $1057-1058$.

${ }^{32}$ Id. at 1059.

33 See Wagner, supra. note 4. 
majority opinion. The majority says that EPA is "free to pick any point between zero and a hair below the concentrations yielding London's Killer Fog. ${ }^{134}$ That assertion is a gross exageration. Three data points illustrate the extreme hyperbole in the court's description of the upper boundary of EPA's discretion. First, the London Killer Fog of 1952 is believed to have killed about 4,000 people per week. ${ }^{35}$ Second, those catastrophic consequences of air pollution resulted from concentration levels approximately fifty times the maximum levels permitted by the particulate and ozone standards in effect before EPA conducted the rulemakings at issue. ${ }^{36}$ Third, numerous studies completed after EPA set the prior standards have found that concentrations of ozone and particulates below the prior standards produce health effects more severe and more widespread than EPA had reason to believe when it set the prior standards. ${ }^{37}$ Thus, in order to defend a decision to set new standards that are "a hair below the concentrations yielding London's Killer Fog," EPA would have to say something like: "In light of the new evidence that suggests more severe health effects than we previously believed to result from ozone and particulates in concentrations lower than the ceilings we previously established, we hereby increase fifty-fold the primary ozone and particulate standards and permit concentrations that we estimate will produce 3900 deaths per week, a mere 202,800 deaths per year. We conclude that these new, relaxed standards that allow greater pollution than the United States has ever experienced are 'requisite

${ }^{34}$ Id. at 1037.

35 See William Logan, Mortality in the London Fog Incident, 1952, The Lancet, Feb. 4, 1053, at $336-338$.

$36 \quad 175$ F. 3d at 1036-1037.

3762 Fed. Reg. 38655-38656, 38859-38860. 
to protect the public health' with an 'adequate margin of safety."' No court would uphold such a decision. Scientific uncertainty imposes significant limits on the practical ability of courts to review agency policy decisions, but courts are not quite as impotent as the ATA majority asserts. Of course, no agency would make such an absurd decision anyway.

The majority's description of the bottom of EPA's range of discretion may be accurate, however. The language of section 109(b) is susceptible to a plausible interpretation that would authorize EPA to set standards that produce zero deaths attributable to criteria pollutants, ${ }^{38}$ and the available data can support a finding that only zero concentrations of ozone and particulates will avoid all loss of life caused by ozone or particulates. ${ }^{39}$ EPA has the discretion to choose a zero level of permissible concentration, however, only if courts are the sole source of limits on EPA's discretion. They are not. As I will argue in parts IV and VI, the President is a far more important source of constraints on agency discretion. No President would seriously consider allowing EPA to set primary ozone and particulate standards at zero. As the $\underline{\text { ATA }}$ majority recognized, standards set at a concentration of zero would require complete deindustrialization plus implementation of programs to remove all nonanthropogenic sources of particulates and ozone. ${ }^{40}$ A zero standard is almost certainly unattainable, and no President would seriously consider adoption of a standard that even approaches

38 Indeed, that seems to be the most plausible interpretation of "requisite to the public health" with an "adequate margin for safety."

39 EPA repeatedly referred to all of the adverse health effects, including deaths, of particulates and ozone as lying along a "continuum" with no "discernable threshold" below which the pollutants have no adverse health effects. See, e.g., 62 Fed. Reg. 38656, 38659, 38672, 38859, 38862-38863.

$40 \quad 175$ F. 3d at 1038 note 4. 
zero. Even an ozone standard of 0.07 ppm would require complete elimination of all anthropogenic sources of ozone in some locations at some times. ${ }^{41}$

Once you add the President to the courts as a source of constraints on agency discretion, EPA's range of discretion in the ozone context probably is no greater than 0.07 to $0.10 \mathrm{ppm}$, given present technology and our present understanding of the relationship between ozone and human health. Obviously, President Clinton was willing to acquiesce in a $0.08 \mathrm{ppm}$ standard. It is fair to infer that he would not have been willing to acquiesce in a standard of 0.07 or $0.09 \mathrm{ppm}^{42}$ It is quite possible that hypothetical future President Gore would be willing to acquiesce in a 0.07 or 0.075 ppm standard, given his well-publicized views on the environment. ${ }^{43}$ It is also quite possible that hypothetical future President George W. Bush would be willing to acquiesce in a standard of 0.09, or perhaps even 0.10 ppm. That may be the "compassionate conservative" ozone standard. I doubt that anyone who would have any chance of being elected President would be willing to acquiesce in a standard below 0.07 or above $0.10 \mathrm{ppm}$. A standard below 0.07 would be too expensive in dollars for any politician to tolerate, while a standard above 0.10 would be too expensive in lives for any politician to tolerate. ${ }^{44}$ It is notable that no member of the large and diverse EPA ozone Advisory Committee urged adoption of

41 There are times and places where ozone concentrations exceed $0.07 \mathrm{ppm}$ solely as a result of nonanthropogenic sources. $173 \mathrm{~F} .3 \mathrm{~d}$ at 1036. A high proportion of ozone and particulates have their origin in nonanthropogenic sources. Thus, for instance, about half of the particulates in the air in Florida originate in nonanthropogenic sources in Africa. See Science Notebook, A Breath of Africa in Miami, The Washington Post, July 19, 1999, at A9.

42 See text at notes $117-126,152-157$ infra.

43 See generally Albert Gore, Earth in the Balance (1992).

44 See text at notes $117-126,152-157$ infra. 
a standard outside the range of 0.08 to $0.10,{ }^{45}$ and no commentor urged adoption of a standard outside the range of 0.07 to $0.12 .{ }^{46}$

I do not want to minimize the difference between $0.07 \mathrm{ppm}$ and $0.10 \mathrm{ppm}$. As I will discuss in parts III and IV, that difference can be restated in the form of many thousands of lives and many billions of dollars each year. Thus, EPA (or more accurately, the President) has substantial policymaking discretion under EPA's construction of the statute. It is preposterous, however, to assert that either EPA or the President have the discretion to choose any standard "between zero and a hair below the concentrations yielding London's Killer Fog." That would be true only if you assume both that a court would uphold an EPA decision that increases the permissible concentrations of ozones and particulates fifty-fold and that EPA Administrators and/or Presidents have a preference for committing political suicide.

\section{THE OPINIONS AND THE SCIENCE CHARADE}

In her brilliant article in Columbia Law Review, Wendy Wagner described and documented:

"The Science Charade in Toxic Risk Regulation."177 In a nutshell, every institution of government demands more of science than science can provide. ${ }^{48}$ This pervasive insistence on scientific answers to

4562 Fed. Reg. 38864-38865.

$46 \quad 62$ Fed. Reg. 38862-38865.

47 Wagner, supra. note 4. For other excellent discussions of this phenomenon, see Howard Latin, Good Science, Bad Regulation, and Toxic Risk Assessment, 5 Yale J. on Reg. 89 (1988); William Ruckelshaus, Science, Risk, and Public Policy, 221 Science 1026 (1983); Thomas McGarity, Substantive and Procedural Discretion in Administrative Regulation of Science Policy Questions: Regulating Carcinogens in EPA and OSHA, 67 Geo. L.J. 729 (1979).

48 Wagner, supra. note 4 , at $1646-1668$. 
all important questions forces scientists and agencies to exaggerate the extent to which science can, or has, answered an important question. As Wagner showed, the science charade manifests itself in many ways that distort decisionmaking and that render it difficult for anyone to understand how any healthrelated decision was made. ${ }^{49}$ Thus, for instance, scientists and agencies routinely disguise the important value judgments and massive uncertainties that inhere in all health-related regulatory decisions. ${ }^{50}$

We, the people, are the ultimate source of the science charade. We have a powerful antipathy toward ambiguity and a deep faith in science to resolve all important disputes about human health. ${ }^{51}$ This powerful set of feelings and beliefs is magnified in the context of regulation of toxic risks. We will not tolerate either a decision that creates an avoidable risk of loss of life or a decision to spend large sums of money to avoid uncertain public health risks. ${ }^{52}$ In short, we will not tolerate either uncertainties or trade offs in the context of regulation of toxic risks. Not surprisingly, our agents in government mirror our feelings and beliefs and translate them into statutes and judicial decisions. ${ }^{53}$

There is a problem, however. The field of toxic risk regulation is characterized both by the need to make tradeoffs between lives and dollars and by massive uncertainties with respect to the

49 Id. at 1673-1689.

50 Id. at $1628-1650$.

51 Id. at 1651-1654.

52 This is attributable in part to a combination of our irrational fear of toxic substances and our demonization of firms that create toxic substances. See Michael Gerrard, Demons and Angels in Hazardous Waste Regulation: Are Justice, Efficiency, and Democracy Reconcilable? 92 Northwestern L. Rev. 706 (1998).

53 See Wagner, supra. note 4, at 1646-1668. 
magnitude of those trade offs.$^{54}$ We and our agents in the legislative and judicial branches simply will not tolerate that reality, however, as many scientists have discovered when they have attempted to explain the limits of science to a legislative or judicial forum.

Wagner described scores of occasions on which legislative and judicial bodies have refused to accept the basic realities that pervade toxic risk regulation and have insisted that scientists and agencies answer questions that science cannot answer. ${ }^{55}$ The best single example is the Supreme Court's decision in Industrial Union Department, AFL-CIO v. American Petroleum Institute,${ }^{56}$ popularly known as Benzene. An agency concluded that it is impossible to determine the level of exposure at which a substance that is known to induce cancer in humans at high exposure levels begins to induce cancer in humans at lower exposure levels. ${ }^{57}$ That is not a controversial conclusion in the scientific community. ${ }^{58}$ Yet, when the agency confronted the Supreme Court with that regretable limit on the capability of science, a four-Justice plurality simply ordered the agency to do the impossible. ${ }^{59}$ The plurality went on to demonstrate the Justices' abysmal ignorance of elementary toxicology by providing hypothetical

${ }^{54}$ See sources cited in note 47 supra. See also text at notes 73-79, 92-124 infra.

55 Wagner, supra. note 4, at 1654-1671.

56448 U.S. 607 (1980).

57 Id. at 624-625.

58 It is usually impossible to determine directly whether exposure to low levels of a toxin causes serious harm. It is often easy to determine that exposure to higher levels causes serious harm, however. It would then be possible to extrapolate the effects of lower levels if we knew the shape of the doseresponse curve. In most cases, however, it is impossible to know the shape of the dose-response curve.

59448 U.S. at 639-640. 
illustrations of large and small risks that have amused and bewildered scientists ever since. ${ }^{60}$ In describing the hypothetical small and large risks, the Justices omitted data that are crucial in assessing toxic risks. ${ }^{61}$ Moreover, the risk the Justices characterized as "plainly acceptable" probably exceeds the risk they characterized as "plainly unacceptable."162

The ATA case is laced with symptoms of the science charade. The language of section 109(b) provides a good starting point. Congress required EPA to establish a primary standard for each criteria pollutant at a level "requisite to protect the public health" with an "adequate margin of safety" and a secondary standard "requisite to public welfare." The decisionmaking standard applicable to primary standards is a good illustration of health and safety absolutism. It suggests strongly that EPA is required to protect public health at all costs. Every court that has addressed the question has reached that

60 The Court said: "Some risks are plainly acceptable and others are plainly unacceptable. If, for example, the odds are one in a billion that a person will die from cancer from by taking a drink of chlorinated water, the risk clearly could not be considered significant. On the other hand, if the odds are one in a thousand that regular inhalation of gasoline vapors that are $2 \%$ benzene will be fatal, a reasonable person might well consider the risk significant and take appropriate steps to decrease or eliminate it." 448 U.S. at 655.

61 The Justices did not describe the size of the exposed population, the duration of exposure, or the shape of the dose-response curve.

${ }^{62}$ Using plausible assumptions -- an average of ten drinks of water per day by a population of 260 million over an average life span of 75 years and a linear dose-response curve -- the risk the Justices characterized as "plainly acceptable" would kill 71,175 people over 75 years -- 949 people per year. [0.000000001 x 260,000,000 x $10 \times 365 \times 75=71,175]$. It is much more difficult to make even a rough estimate of the number of people who would die as a result of the risk the Justices characterized as "plainly unacceptable." How many people "regularly inhale" gasoline vapors? With self-service gas stations ubiquitous everywhere in the U.S. except New Jersey, I would guess that only about 10,000 people fall in this category. Thus, the "plainly unacceptable" risk would kill about ten people -- a tiny fraction of the number that would be killed by the "plainly acceptable" risk.. 
conclusion -- EPA is prohibited from considering either cost or feasibility in setting primary standards. ${ }^{63}$

Taken literally, the language of section 109(b) also seems to require EPA to set primary

standards somewhat below the level at which a pollutant is likely to kill people. Congress believed that EPA could (1) determine through the use of science the concentration of any pollutant at which the pollutant does not kill anyone; (2) set the primary standard a bit below that level; and, (3) set a still lower secondary standard that would avoid other forms of harm, e.g., reduced visibility. Congress also believed that every area of the country could meet the primary standard applicable to each pollutant by 1987 ; it mandated that result by statute in $1977 .{ }^{64}$

At least in the case of particulates and ozone, each of Congress's beliefs was false. EPA can not use science to determine a concentration of particulates and ozone that does not kill some people. Science can only provide rough estimates of the correlation between levels of pollutants and adverse public health effects, including death. Moreover, the best evidence available suggests strongly that the relationship between concentration and health effects lies on a continuum and that there is no level at which these two pollutants do not kill some people. ${ }^{65}$ Thus, if EPA applied the two-step absolute

${ }^{63}$ NRDC v. EPA, 902 F. 2d 960, 969 (D.C. Cir. 1990); American Petroleum Institute v. Costle, 665 F. 2d 1176, 1185 (D.C. Cir. 1981); Lead Industries Ass'n v. EPA, 647 F. 2d 1130, 1148 (D.C. Cir 1980).

6442 U.S.C. $§ 7502$ (1988). As of 1999, many areas still have not met the standards. See 175 F. 3d at 1045-1046.

65 See sources cited in note 39 supra. See also EPA Regulatory Impact Analyses For the Particulate Matter and Ozone National Ambient Air Quality Standards and Proposed Regional Haze Rule, July 16, 1997, at ES- 17-18 [hereinafter cited as RIA] (estimating that the relatively modest increase in the stringency of the ozone and particulate standards required by the two rules would reduce the number of deaths attributable to exposure to particulates and ozone by 3,700 to 17,900 per year.) 
health criterion suggested by a literal reading of section 109(b), it would have to set primary ozone and particulate standards at something like minus $0.2 \mathrm{ppm}$-- zero to satisfy the "requisite to protect the public health" criterion, minus $0.2 \mathrm{ppm}$ to provide "an adequate margin of safety." That would be absurd, of course.

EPA salvaged this incoherent statutory standard by finding ambiguity in the term "public health." It rejected an interpretation of "public health" that would equate the term with freedom from the risk of death attributable to pollution, and it interpreted section 109(b) to allow it to take an "integrative approach" in setting primary standards, rather than the two-step approach that section seems to require. ${ }^{66}$ The courts acquiesced in EPA's creative interpretation. ${ }^{67}$ In the case of ozone and particulates, EPA also implicitly interpreted "protect the public health" with "an adequate margin of safety" to be consistent with thousands of deaths per year. Even if every area of the country were in compliance with the new primary standards the court struck down in ATA, the best scientific evidence available suggests that ozone and particulates would continue to kill several thousand people per year. ${ }^{68}$

EPA's interpretation stretches the statutory language near or perhaps beyond the breaking point. Yet, I find it hard to criticize EPA. An agency has no choice but to engage in disengenuous reasoning when Congress or a court requires it to do the impossible, as both institutions do with considerable frequency in the context of regulation of toxic risks. This background information goes a

66 See 62 Fed. Reg. 38653, 38688.

${ }^{67}$ See Lead Industries Ass'n v. EPA, 647 F. 2d 1130, 1161-1162.

68 See sources cited in note 65 supra. 
long way toward explaining the problem the ATA majority identified and attempted to correct. As I will explain in part IV, once EPA rejected the determinate, but impossible to implement, standard Congress placed in section 109(b), it was left with no way of providing an alternative determinate standard that would satisfy the ATA majority.

The dissenting opinion in ATA also contains a typical symptom of the science charade. The dissenting judge would have upheld EPA's choice of standards because he interpreted EPA as having drawn a line based on differences in kind, rather than differences in degree, of adverse health effects. ${ }^{69}$ He cited passages in the EPA statements of basis and purpose to support that interpretation. Thus, for instance, EPA explained its choice of ozone standards on the basis that "the most certain [ozone-] related effects, while judged to be adverse are transient and reversible." ${ }^{170}$ The dissenting judge interpreted that statement as proof that EPA drew the line between permanent and irreversible effects and transitory and reversible effects, and/or between certain and uncertain effects. That interpretation is demonstrably false, but it is a typical judicial symptom of the science charade. We want science to provide clear answers to all important questions, so we find scientific answers where they do not, and can not, exist.

The EPA statement the dissenting judge relied on may be technically accurate, but it is seriously misleading. Indeed, it was almost certainly included in the agency's statement of basis and purpose in an attempt to mislead a reviewing court. The statement is yet another symptom of the science charade. Since Congress and courts insist that agencies defend their decisions as objective applications of

69175 F. 3d at 1059.

7062 Fed. Reg. 38868. 
science, an agency must use words that mislead a court into thinking that is what it has done.

If you parse the words the dissenting opinion quotes, and consider those words in the context of the several thousand pages in which EPA explains the basis for its actions, it is easy to spot the dissenting judge's interpretive error. Two features of EPA's explanation are sufficient alone to demonstrate the judge's error. First, EPA predicted that even compliance with the new primary standards is likely to produce several thousand deaths per year attributable to ozone and particulates. ${ }^{71}$ Death is not a "transient and reversible" effect, so EPA could not have meant to say that the health effects below 0.08 ppm are "transient and reversible." It said only that the most "certain" effects are "transient and reversible." Thus, for instance, at 0.08 , non-fatal incidents of pulmonary distress are more certain than death, but that is also true at every other level. Second, EPA repeatedly referred to the health effects of ozone and particulates as lying on a "continuum," a relationship that is confirmed by looking at the EPA tables that show the estimated correlations between concentration levels and health effects. $^{72}$ EPA predicted only differences in degrees of health effects, not differences in kinds of effects. The estimated number of deaths varies with the concentration level, but EPA predicted some deaths at each level it considered, including the level it chose. Of course, the degree of certainty of deaths increases from the $0.08 \mathrm{ppm}$ level to the $0.09 \mathrm{ppm}$ level, but it also increases at every other level.

At this point, it is useful to describe briefly the manner in which EPA (or anyone else) attempts to estimate the health consequences of exposure to toxic substances, and the massive range of uncertainty that surrounds all such estimates. EPA begins with studies that "find" particular relationships

71 See sources cited in notes 39 and 65 supra.

72 See sources cited in note 39 supra. 
between different levels of exposure and various health effects. In the ozone and particulate rulemakings, EPA considered over 100 epidemiological and human clinical studies that had been published since it last changed the primary standards. ${ }^{73}$ Each study looked at a different population that was exposed to different concentrations of pollutants for different periods of time. Some were "negative effects" studies,${ }^{74}$ i.e., they found no statistically significant difference in health effects of exposure to the different concentrations that were studied. Most found statistically significant differential effects, however, and most found adverse effects, including deaths, at levels well below the pre-existing primary standards. ${ }^{75}$ The studies varied greatly, however, with respect to the magnitude of both the absolute effects and the differential effects of exposures to the concentrations studied. Each study was imperfect in important respects, e.g., the researchers could not definitively exclude the potential effects of other variables, and the findings of each study were qualified with reference to wide ranges of uncertainty attributable to variables such as sample size.

Each study was critiqued in detail in the over 100,000 comments. EPA responded to those critiques and explained why it attached greater significance to some studies than to others. EPA emphasized repeatedly that it "places greater weight on the overall conclusions derived from the studies ... than on the specific concentration-response functions and quantitative risk derived from them" because of the "significant uncertainty" that surrounds the findings of any individual study. ${ }^{76}$

\footnotetext{
73 The studies are listed at 62 Fed. Reg. 38709-38711, 38894.

7462 Fed. Reg. 38660.

7562 Fed. Reg. 38656-38659.

7662 Fed. Reg. 38656.
} 
EPA then used its analysis of the studies as the basis to construct a quantitative risk assessment. The process of risk assessment involves extracting findings from various studies, attaching differential weights to those findings based on an evaluation of the likely level of validity assigned to each, and then applying a variety of statistical techniques to obtain estimates of the likely adverse health effects of exposures to the concentrations under consideration. Thus, for instance, EPA estimated that retention of the pre-existing ozone and particulate standards, rather than adoption of the new standards, would produce between 3,300 and 17,900 deaths per year. ${ }^{77}$ To its credit, EPA emphasized repeatedly the uncertainties that affect all such estimates, but it was not completely candid in disclosing the full magnitude of those uncertainties. As Howard Latin and Tom McGarity have shown "the estimates provided by existing risk assessment models could vary a millionfold, depending upon the model selected."178 Albert Nichols and Richard Zeckhauser explain how different choices of plausible values for each of only three of the many factors that are used in a risk assessment cause the resulting estimates to vary "by a factor of 35,000."179

EPA was less than fully candid in another respect as well. It did not make explicit findings with respect to the differential effects of alternative concentrations on the number of deaths caused by

77 RIA at ES-17-18.

78 Thomas McGarity, Some Thoughts on "Deossifying" the Rulemaking Process, 41 Duke L.J. 1385, 1403 (1992); Latin, supra. note 47, at 91-92. See also Gerrard, supra. note 52, at 727-730. The range of uncertainty may be somewhat lower in the context of ozone and particulates because EPA could use human epidemiological studies rather then the laboratory animal studies that typically must be used as the basis for estimating carcinogenic risks.

79 Albert Nichols \& Richard Zeckhauser, The Perils of Prudence: How Conservative Risk Assessments Distort Regulation, Regulation, Nov./Dec. 1986, at 13,18. 
pollution, e.g., it did not estimate the number of additional deaths that could be avoided by adopting an ozone standard of 0.07 rather than $0.08 \mathrm{ppm}$. It is easy to infer such an estimate from analysis of the EPA's risk assessment, however. EPA's Advisory Committee noted that the data gathered and evaluated by EPA show a "continuum of biological responses down to background [nonanthropogenic source] concentrations" ${ }^{180}$ and no "bright line" that distinguishes the differential effects of any pair of alternative concentrations. ${ }^{81}$ In other words, EPA would have made approximately the same estimate of lives saved by setting the standard at 0.07 , rather than 0.08 , that it made with respect to the number of lives saved by choosing a standard of 0.08 , rather than 0.09 . In both cases, of course, the estimates would be subject to a massive range of uncertainty.

It follows that the ATA majority was correct in concluding that EPA's construction of section 109(b) provides EPA, and reviewing courts, no "determinate, binding standard" that can be used as the basis for choosing a primary ozone standard, at least within the range of $0.00 \mathrm{ppm}$ to $0.12 \mathrm{ppm}{ }^{82} \mathrm{At}$ this point, the sources of the ATA majority's concerns become apparent. If EPA chose zero concentration standards, it would shut down the entire economy. ${ }^{83}$ If it chose to retain the existing standards, it would be accepting the death of about 20,000 people per year. ${ }^{84}$ Even the choice it made to increase the stringency of the standards a bit required it to choose between saving an additional

${ }^{80} 62$ Fed. Reg. 38863.

81 Id. at 38862.

$82 \quad 175$ F. 3d at 1038.

83 Id. at 1038 note 4.

${ }^{84}$ See sources cited in notes 39 and 65 supra. 
10,000 or so lives per year and avoiding additional costs of about fifty billion dollars a year. ${ }^{85}$ This seems like an enormous amount of policymaking discretion to confer on someone Chief Justice Rehnquist has referred to as a "politically unresponsive administrator. ${ }^{186}$ Moreover, the D.C. Circuit has been assigned the task of reviewing EPA's line-drawing decisions. It is hard to see how the court can perform its duties effectively in light of the massive indeterminacy created by EPA's construction of section 109(b).

It is easy to sympathize with the extreme frustration of the ATA majority. It is also easy to criticize the majority's solution, however, and to urge its rejection. The majority holds that EPA's construction of section 109(b) is unconstitutional and that EPA cannot take any actions to implement that section until it adopts a new construction that includes "determinate, binding standards" that EPA and courts can use to determine "how much [pollution] is too much. ${ }^{187}$ This is the point at which the majority fell prey to the science charade. It assigned EPA a task that EPA cannot perform. Indeed, no institution can perform that task.

\section{ALTERNATIVE CONSTRUCTIONS OF THE CLEAN AIR ACT}

In this section, I will evaluate four potential alternative constructions of section 109(b) that might appear to comply with the court's mandate. Before I begin that task, however, it is important to recognize that the general problem identified by the ATA majority is ubiquitous. We have tens of

\footnotetext{
85 See RIA at ES-17-20.
}

86 That is how Chief Justice Rehnquist characterized the Administrator of OSHA in a similar context. See Benzene, 448 U.S. at 686-687.

87175 F. 3d at 1034, 1038. 
thousands of statutory and regulatory provisions that use numbers to draw critical distinctions. In a high proportion of cases, the line drawing process that produced those numbers is indistinguishable from the process EPA used to set the ozone standard at $0.08 \mathrm{ppm}$, rather than 0.07 or 0.09 . Yet, the Republic has not fallen.

Two readily accessible numbers illustrate the point. You must be 18 to vote and 21 to buy alcohol in the United States. In both cases, the line drawing is based on maturity, but everyone knows that maturity does not arrive as a birthday present on either your 18th or 21st birthday. Maturation is a process that is both gradual and variable. Like the health effects of ozone and particulates, the correlation between age and maturity lies on a continuum with approximately equal intervals separating 18 year olds from 19 year olds, 19 year olds from 20 year olds, and 20 year olds from 21 year olds. We could as easily defend decisions to make 21 the minimum age for voting and 18 the minimum age for drinking. Indeed, many states had minimum drinking ages below 21 until Congress effectively forced them to adopt 21 as the minimum age, and 21 was the minimum voting age until Congress changed it to 18 a couple of decades ago.

Of course, those necessarily arbitrary exercises in line-drawing were performed by Congress, thereby avoiding both potential attacks under the nondelegation doctrine and the concerns that underlie the nondelegation doctrine. But Congress cannot possibly make all of the line-drawing decisions that have produced tens of thousands of legally-operative numbers in the Code of Federal Regulations. The counter-argument voiced by some is that Congress at least can make the few "fundamental" policy 
decisions that agencies now make every year ${ }^{88}$ EPA's ozone and particulate rules would seem to fall in that category. They require some institution to make tradeoffs between sacrificing about 10,000 lives per year and spending about fifty billion dollars a year in additional pollution control costs. ${ }^{89}$

The argument that Congress should make all "fundamental policy decisions" sounds good in theory, but it collapses completely upon consideration of the institutional limitations of Congress. As I have argued elsewhere, Congress is plagued by a combination of characteristics that render it totally unsuited to the task of drawing quantitative lines in the context of toxic risk regulation. ${ }^{90}$ Those characteristics include: inadequate knowledge, inadequate foresight, inadequate expertise, and a host of severe collective action problems. Congress rarely chooses to use numbers when it enacts regulatory legislation. On the rare occassions when it has chosen to act in that manner, the results have been disastrous. ${ }^{91}$ I certainly do not want to tell Congress that it must act in that manner. I do not want to demand that the same institution that produced the absurdly unrealistic language of CAA section 109(b)

${ }^{88}$ See Benzene, 448 U.S. at 687 (Rehnquist, J., concurring).

${ }^{89}$ See RIA at ES-17-20.

${ }^{90}$ See Richard Pierce, The Role of the Judiciary in Implementing an Agency Theory of Government, 64 N.Y.U.L. Rev. 1239, 1244-1247 (1989); Richard Pierce, The Role of Constitutional and Political Theory in Administrative Law, 64 Tex. L. Rev. 469, 472-504 (1985).

${ }^{91}$ The best examples of this rare type of congressional action are the Delaney Clauses, the Natural Gas Policy Act of 1978, and the hundreds of absurdly unrealistic statutory deadlines Congress imposes on regulatory agencies. The disastrous effects of these attempts to legislate with precision have been documented thoroughly. See, e.g., Jerry Mashaw, Richard Merrill \& Peter Shane, Administrative Law: The American Public Law System 128-147 (4th ed. 1998) (discussing some of the many problems created by the Delaney Clauses); Richard Pierce, Reconstituting the Natural Gas Industry from Wellhead to Burnertip, 9 En. L.J., 11-16 (1988) (discussing some of the many problems created by he Natural Gas Policy Act); Davis \& Pierce, supra. note 19, at $\$ 12.3$ (discussing some of the many problems created by statutory deadlines). 
must establish quantitative standards applicable to each of 130 criteria pollutants.

\section{A. $\underline{\text { Cost-Benefit-Analysis }}$}

I will begin by evaluating an alternative construction of section 109(b) that the ATA majority did not urge the EPA to consider. The ATA court could not urge the EPA to adopt a construction that permits, or requires, cost-benefit-analysis (cba). The D.C. Circuit has interpreted section 109(b) to preclude consideration of costs, and a panel of the D.C. Circuit is required to adhere to decisions issued by other panels. ${ }^{92}$ There is no doubt, however, that the judges who comprised the majority in $\underline{\text { ATA }}$ would like EPA to adopt a statutory construction that permits, or requires, cba. Both judges are economically-oriented former academics who were appointed by President Reagan, ${ }^{93}$ and the author of the opinion has urged agency use of cba in similar contexts. ${ }^{94}$ In fact, in all likelihood, the judges who comprised the ATA majority were motivated in part by their desire to create a vehicle through which the en banc circuit will have the opportunity to reconsider, and potentially to overrule, the 1980 panel decision that held that EPA can not consider costs in implementing section 109(b). ${ }^{95}$ (It is an interesting

92 See cases cited in note 63 supra.

93 Judge Williams taught natural resources law at University of Colorado, while Judge Ginsburg taught antitrust law at Harvard.

94 Judge Williams wrote part I of the ATA opinion. 175 F. 3d at 1033 note *. In 1991, he wrote a similar opinion in which he suggested that OSHA adopt a statutory construction that permits, or requires, it to use cba. International Union, UAW v. OSHA, 938 F. 2d 1310, 1318-1321 (D.C. Cir. 1991).

95 The D.C. Circuit would have to stretch the language of section 109(b) even further to hold that it permits EPA to consider costs, but such an interpretation is potentially defensible. CAA section 109(b) is one of only two federal statutory provisions that has been held to preclude an agency from considering the costs and feasibility of the standards it imposes. Wagner, supra. note 4, at 1668. Cass Sunstein and Richard Stewart have argued that all regulatory statutes should be interpreted to permit 
irony that the excessive discretion that the ATA majority found was attributable in part to a prior judicial decision that had the putative effect of limiting EPA's discretion.)

Contrary to the apparent belief of the ATA majority, cba has little, if any, potential value to a reviewing court as a means of limiting agency discretion. Indeed, a cba is likely to be useful to a court only as a modest source of reassurance that the agency has chosen one of countless standards that fall within the massive range of overlap between plausible estimates of the costs and benefits of alternative standards. Cba cannot provide an "objective" estimate of costs and benefits because its results depend critically on value judgments made by the analyst. Cba also cannot provide a "determinate" standard because it is capable of producing only extraordinarily broad ranges of estimates of costs and benefits. Agency rules almost always have the potential to create a wide range of estimated benefits that overlaps significantly with a wide range of estimated costs. Lisa Heinzerling's analysis of John Morrall's famous cost of lives saved table is invaluable to illustrate those characteristics of cba. ${ }^{96}$

The results of a cba can be summarized in one of two ways: estimated costs versus estimated benefits or estimated cost per life saved. In 1986, John Morrall, an economist at the Office of Management and Budget, used the second method to summarize the results of cbas he had performed of forty-four federal health and safety rules. ${ }^{97}$ According to Morrall's table, twenty-four of those rules required incurrence of compliance costs in excess of seven million dollars per life saved, the high end of

consideration of costs. Richard Stewart, Regulatory Jurisprudence: Canons Redux? 79 Cal. L. Rev. 807, 817 (1991); Cass Sunstein, After the Rights Revolution: Reconceiving the Regulatory State 196198 (1990).

96 Lisa Heinzerling, Regulatory Costs of Mythic Proportions, 107 Yale L.J. 1981 (1998).

97 John Morrall, A Review of the Record, Regulation, Nov./Dec. 1986, at 25. 
the range of economists' estimates of the value we place on reducing risks to our lives. ${ }^{98}$ Morrall listed thirteen rules with estimated costs per life saved in excess of one hundred million dollars. He listed three rules with estimated costs per life saved in excess of a billion dollars. Morrall provided only a limited description of the methodology he used to create his table and none of the data he used for that purpose. Over the next twenty-two years, scores of scholars and witnesses before congressional Committees quoted the Morrall table uncritically to support the proposition that federal regulatory agencies often act irrationally by issuing many rules that require society to incur costs that vastly exceed benefits. ${ }^{99}$ Lisa Heinzerling's 1998 article in Yale Law Journal should bring that routine practice to an abrupt halt. More importantly for present purposes, that article demonstrates what Heinzerling calls "the perils of precise quantification" -- a recurring symptom of the science charade. ${ }^{100}$

Heinzerling did what no one else had bothered to do. She obtained all of the data that were the basis for Morrall's estimates. She then used a process of reverse engineering to identify Morrall's methodology, including the many places where he used a particular number of lives saved from a wide range of estimated lives saved and the many places where he inserted contestable values into the calculation process. Morrall often ignored all benefits except lives saved, even though many of the rules had other significant health and environmental benefits. ${ }^{101}$ He often chose an estimate of lives saved that
98 Id. at 30.
99 Heinzerling, supra. note 96, at 1983-1984, 1993-1998.
100 Id. at 1986.
101 Id. at 2060-2064. 
was at the low end of the wide range of estimated lives saved that the available data would support. ${ }^{102}$ He then reduced that number further by using the controversial practice of discounting the value of lives saved in future years. ${ }^{103}$

After she identified Morrall's data sources and methodology, Heinzerling then calculated alternative cbas for each of the twenty-four rules that Morrall had identified as excessively costly. ${ }^{104}$ In each case, she used estimates of health effects that were within the range of estimates supported by the available data and, with the exception of her refusal to discount the value of future lives saved, she used a methodology that is within the mainstream of the cba literature. Based on her plausible alternative cbas, Heinzerling concluded that most of the rules Morrall considered outrageously expensive actually were "bargains."105

Heinzerling does not prove that Morrall's cbas are wrong and that hers are right. That is not her point. Rather, she demonstrates that the inherent range of uncertainty in performing a cba is massive. Heinzerling's analysis of Morrall's cba estimate of OSHA's formaldehyde rule typifies the situation she found. Morrall estimated that the formaldehyde rule would cost $\$ 72$ billion per life

102 Id. at $2025-2040$.

103 Id. at 2017-2024, 2043-2056. Most economists consider discounting of future lives saved essential, but many moral philosophers consider it indefensible. For a brief introduction to this debate, compare John Donohue, Why We Should Discount the Views of Those Who Discount Discounting, 108 Yale L. J. 1901 (1999), with Lisa Heinzerling, Discounting Life, 108 Yale L.J. 1911 (1999). For what it's worth, I agree with the economists. I do not believe, however, that economists, or economically-oriented judges are competent to make such decisions. They should instead be made by politically-accountable officials, e.g., the President.

104 Id. at 2017-2056.

105 Id. at 1985. 
saved. ${ }^{106}$ Heinzerling explained how OSHA derived its sharply contrasting estimate of \$21.8 million per life saved ${ }^{107}$-- less than one three thousandth of Morrall's estimate. She also showed that even OSHA may have underestimated the number of lives that are likely to be saved by the rule, thereby inflating its estimate of cost per life saved. ${ }^{108}$ Indeed, the D.C. Circuit criticized OSHA for using data and methodologies that created a downward bias in its estimate of lives saved. ${ }^{109}$ Heinzerling then explained how OSHA could have used the available data with respect to the health benefits of the rule other than avoidance of fatalities to support an estimate that the formaldehyde rule actually saved lives at a negative net cost per life saved, although she identified serious problems with that interpretation of the data as well. ${ }^{110}$ Thus, we can use cba only to show that the plausible estimates of cost per life saved by the formaldehyde rule range from a net negative cost, to OSHA's $\$ 21.8$ million, to Morrall's $\$ 72$ billion. Heinzerling found similar differences of over 1000-fold between Morrall's cbas and plausible alternative cbas for the other rules Morrall claimed to be outrageously expensive. ${ }^{111}$ She even found cases in which Morrall's own cbas of the same rule differed by a factor of over 10-fold. ${ }^{112}$ Heinzerling's careful study of alternative cbas persuaded her that we should abandon

106 Morrall, supra. note 97, at 30.

107 Heinzerling, supra. note 96, at 2025-2028.

108 Id. at 2027-2028.

109 International Union, UAW v. Pendergrass, 878 F. 2d 389, 395-396 (D.C. Cir. 1989).

${ }^{110}$ Heinzerling, supra. note 96, at 2028.

111 Id. at 2017-2060.

112 Id. at 2019-2020, 2032. 
completely the use of cba as a decisionmaking tool. She concluded that the "danger of misinterpretation and misunderstanding is [too] great."113 My reading of her study persuades me that we should continue to use cba. Heinzerling identified and discussed numerous cases in which agencies declined to issue proposed rules because the agencies concluded that a proposed rule would impose costs massively disproportionate to the benefits it would yield. ${ }^{114}$ Those cases illustrate the value of cba to a decisionmaker.

I agree completely with Heinzerling's criticism of many cbas as illustrative of the perils of precise quantification, however. We should respond to that serious problem by placing greater emphasis on candor in disclosing both the important value judgments that underlie any cba and the massive range of uncertainty inherent in cba. ${ }^{115}$ No agency, OMB analyst, witness, or scholar should summarize the results of any cba with an inherently misleading single number or set of numbers, e.g., the estimated cost per life saved is $\mathrm{x}$, or the estimated costs are $\mathrm{y}$ and the estimated benefits are $\mathrm{z}$. The results of any cba should be summarized only in the form of the range of results that can be supported through use of the available data and plausible methodologies. Thus, for instance, the cba for OSHA's formaldehyde rule should be summarized as producing cost estimates between zero and $\$ 72$ billion per life saved.

113 Id. at 2065.

114 Id. at 2000-2014. Heinzerling also criticized the cbas that were the bases for those decisions. See id. at notes 101, 109, 117, 118, 124, 129, 160, 163, and 195. Granting Heinzerling's point that cba is too indeterminate and value laden to be useful to a court, I believe that it is entirely appropriate for a politically accountable official, i.e., the President, to make the value judgements inherent in using cba as a decisionmaking tool. We vote for a Presidential candidate because we believe that he shares our values and will apply those values in making policy decisions.

115 Heinzerling considered, but rejected, those methods of addressing the problem. Id. at 2064-2070. 
Heinzerling's study provides powerful evidence to refute the belief of many that cba is a useful tool for application by a reviewing court. Heinzerling found only two cases in which a court rejected an agency rule based on the court's application of cba. ${ }^{116}$ That is not surprising, given the extraordinarily wide range of estimates that alternative cbas can yield. Scientifically illiterate and politically unaccountable judges are incompetent to resolve the science based, data-based, or value-based disputes that produce cba estimates that routinely vary by a multiple of over 1000 . Thus, an interpretation of CAA section 109(b) that requires EPA to use cba in implementing CAA section 109(b) would not satisfy the ATA majority's demand for a "determinate, binding standard" that would allow EPA and reviewing courts "to state intelligently how much is too much." Cost-benefit-analysis is far too value-laden and indeterminate to perform that function.

I would much prefer an interpretation of section 109(b) that permits EPA to consider cba for two other reasons, however. First, I am confident that EPA did, in fact, consider its cba of the ozone and particulate rules, notwithstanding its claims to the contrary. ${ }^{117}$ EPA states that it never considers cost in making decisions under section 109(b). ${ }^{118}$ Yet, it always conducts a cba before it takes any such action. Thus, for instance, EPA prepared a 718-page cba of the proposed ozone and particulate rules. ${ }^{119}$ EPA says that it prepares a cba only to aid states in the process of developing implementation

116 Id. at 2005-2008.

117 EPA's use of cba in its prior decisionmaking under CAA section 109(b) has been well documented. See Wagner, supra. note 4, at 1641-1644.

118 See, e.g., 62 Fed. Reg. 38701.

119 See RIA. 
plans, and never considers the cba in its own decisionmaking. ${ }^{120}$ Yet, the cba is available to anyone on the internet. ${ }^{121}$ I cannot believe that no one in the White House, no one in the Administrator's office, and no member of the Advisory Committee spent the two minutes necessary to obtain access to the cba and the half hour necessary to read the 22-page executive summary. If no one in the decisionmaking process actually considered costs, I cannot imagine how EPA chose an ozone standard of 0.08 ppm, rather than $0.07,0.06$, etc. It is clear that each reduction in concentration saves lives. ${ }^{122}$ It follows that any decisionmaker who actually ignores cost and feasibility would choose a lower standard than EPA chose.

At some point, the EPA Administrator undoubtedly met with the President to tell him that she was considering taking an action that she thought might save about 10,000 lives per year. No President would acquiesce in a decision of that magnitude without first discussing it with the Administrator. I cannot imagine any President who would not then ask the Administrator for some estimate of the cost of the action before acquiescing in the action proposed by the Administrator. I also cannot imagine any President who would acquiesce in the Administrators' proposed action if she responded with either: "I have no clue," or "I think it will require the deindustrialization of the United States." (I doubt that President Clinton has forgotten James Carville's famous advice: "It's the economy, stupid.") Thus, an interpretation of section 109(b) that allows EPA to consider costs would further the goal of transparent decisionmaking by allowing EPA to explain how it used cba in its decisionmaking process.

12062 Fed. Reg. 38701.

121 Id. at 38701.

122 See sources cited in notes 39 and 66 supra. 
Second, the ATA court would have found the EPA's cba reassuring if it had been given access to that document. Using the best available sources of data, plausible assessments of health risks, and defensible value-based methodological assumptions, EPA estimated that the new rules would cost an estimated $\$ 46.6$ billion per year and would yield monetizable benefits in the range of $\$ 21.5$ billion to $\$ 118$ billion per year. ${ }^{123}$ To its credit, EPA's cba repeatedly emphasized the uncertainties inherent in the process of preparing a cba. Cost-benefit-analysis is a useful decisionmaking tool only if the decisionmaker understands the massive range of uncertainties inherent in the process of estimating the costs and benefits of a proposed rule.

I have only one serious criticism of EPA's cba. By summarizing its cost estimate with a single figure, instead of a wide range, ${ }^{124}$ and by summarizing its benefits estimate with reference to a relatively narrow range, EPA also has succombed to the science charade. It stated the results of its cba with much greater precision than the underlying science permits. EPA stated its benefit estimate in the form of a range, but the range it reported is far too small. Given the enormous range of uncertainty apparent in the findings of the one hundred plus epidemiological studies and the wide range of defensible value judgments that EPA could have used to calculate the estimated benefits of the rules, a competent analyst could easily defend as plausible benefit estimates that are both far below the low end of the

123 RIA at ES-12-22.

124 Like Heinzerling, I have emphasized the range of uncertainty that affects benefit estimates. Cost estimates also have wide ranges of uncertainty. The range of uncertainty of the cost of EPA's ozone and particulate rules is unusually large. The rules would only require states to take whatever actions each considers necessary to attain the new standards. Thus, the analyst had to predict how each state would respond to the new standards and how each source would respond to each new state rule over the next decade or so. 
range EPA reported and far above the high end of the range EPA reported. ${ }^{125}$ It is also apparent from the underlying data that EPA could have used cba to support its choice of any standard between 0.07 and 0.10 ppm. ${ }^{126}$ Thus, judicial access to the cba would be of no help whatsoever to a court that wants to be able to limit EPA's discretion. By contrast, it is helpful to a President because he can use his values as the basis for choosing where to draw the line between protection of public health and costs, given the massive uncertainties inherent in estimating both the costs and benefits of alternative standards. In a democracy, the President's values are the best available proxy for the values of the people.

\section{B. Zero Health Risks}

After noting that EPA was precluded from using cba by the D.C. Circuit's prior opinions, ${ }^{127}$ the ATA majority suggested other ways in which EPA might be able to comply with the court's mandate. First, "EPA could make its criterion the eradication of any hint of direct health risk."128 The majority

125 The literature on risk assessment and cost-benefit-analysis identifies and illustrates scores of ways in which an analyst's choice of plausible variables and methodologies can yield variations in benefit estimates that vary by a millionfold. See Heinzerling, supra. note 96: Wagner, supra. note 4; Latin, supra. note 47; McGarity, supra. note 78; Nichols \& Zeckhauser, supra. note 79. Thus, for instance, Morrall might well rely on the findings of the several "negative effects" studies as the basis for his belief that the ozone and particulate rules would produce no health benefits. Conversely, use of the "Oregon approach," suggested by the ATA majority, would produce benefit estimates far above the upper end of the range of estimates reported by EPA. See text at notes 140-146 infra.

126 See sources cited in notes 39 and 65 supra.

127175 F. 3d at 1038.

128 Id. at 1038. 
recognized that "[t]his approach is certainly determinate enough."129 It also noted, however, that EPA has shown "no inclination to adopt it."130 The reasons are obvious. As the majority recognizes, a zero health risk criterion could be satisfied only with zero concentrations of ozone and particulates, which in turn could not be attained even with complete deindustrialization. ${ }^{131}$ No one who could be elected President would make that tradeoff between public health and prosperity. Indeed, public health would not fare well for long in an impoverished nation.

The majority went on to suggest that EPA might choose a variant of a no adverse health effects criterion. For this purpose, EPA "might ... use standards drawn from other areas of law, such as the familiar 'more probably than not' criterion." ${ }^{1132}$ In other words, EPA could use a criterion that requires it to set emissions levels that will eliminate the probability of adverse health effects. Given the available data on the relationship between human health and exposure to ozone and particulates, this criterion also would require EPA to set maximum permissible concentrations at levels that cannot be attained even with complete deindustrialization. There is no level of ozone or particulates above zero that does not produce a probability of loss of life. ${ }^{133}$ It is hard to believe that the two economically-oriented conservative Republican judges who formed the ATA majority are seriously urging EPA to adopt a decisionmaking standard that requires complete deindustrialization. Whatever the majority's agenda
129 Id. at 1038.
${ }^{130}$ Id. at 1038.
131 Id. at 1038.
132 Id. at 1038.
133 See sources cited in notes 39 and 65 supra. 
may be, that cannot be among its goals.

\section{The "Modest Deviation from Stringency" Criterion}

The ATA majority suggested another potential constitutional construction of section 109(b) by reference to another agency's constitutionally-permissible construction of a similar statutory provision. ${ }^{134}$ In 1991, a D.C. Circuit panel held that the Occupational Safety and Health Administration's (OSHA) construction of section 3(8) of the Occupational Safety and Health Act violated the nondelegation doctrine by providing decisionmaking criteria that were inadequate to limit OSHA's discretion or to provide a basis for judicial review of OSHA actions. ${ }^{135}$ That 1991 opinion was written by the author of the majority opinion in ATA. The two opinions are almost identical with respect to their holdings, reasoning, and choice of remedies. The only significant difference between the two opinions is with respect to the court's treatment of cost-benefit-analysis. Since the D.C. Circuit had not previously held that section 3(8) precludes OSHA from using cba, the court was free to suggest that OSHA adopt a construction of section 3(8) that requires it to use cba as a way of complying with the court's mandate to adopt a constitutional construction of section 3(8). The court suggested that OSHA comply with its mandate in that manner. ${ }^{136}$

OSHA rejected the court's suggestion. Instead, it attempted to satisfy the court's mandate by adopting a statutory construction that requires OSHA to issue safety standards that provide "a high

134175 F. 3d at 1037.

${ }^{135}$ International Union, UAW v. OSHA, 938 F. 2d 1310.

136 Id. at 1318-1320. 
degree of worker protection."137 In a 1994 opinion, the same panel held that OSHA's new construction satisfied the nondelegation doctrine by precluding the agency from doing "nothing at all" once it identifies a significant safety risk. ${ }^{138}$ Presumably, the ATA majority would be equally content with an EPA construction of CAA section 109(b) that requires EPA to issue primary air quality standards that provide a "high degree of protection" of the health of people who are exposed to criteria pollutants. After all, both the 1991 and 1994 opinions were written by the same judge who wrote the majority opinion in $\underline{\text { ATA. }}$.

I do not understand how EPA's adoption of a "high degree of protection" criterion for applying section 109(b) would have any effect whatsoever on its degree of discretion in issuing primary air quality standards or on a court's ability to review EPA actions taken pursuant to section 109(b). That construction seems to be nothing more than a way of paraphrasing the language of section 109(b) and the language EPA already uses to describe the criteria it uses to apply that section. A decisionmaking standard that requires a "high" degree of protection of human health obviously says nothing that is the least bit helpful in deciding how "high" is too high or too low. At most, such a standard would preclude EPA from "doing nothing at all" or from issuing ozone and particulate standards that are "a hair below the concentrations yielding London's Killer Fog." As I demonstrated in Part II, however, EPA does not have that discretion today.

The construction that OSHA adopted and the court approved obviously would have no effect on EPA's discretion to choose any standard at or below the $0.08 \mathrm{ppm}$ standard it chose in its ozone

13758 Fed. Reg. 16615.

138 International Union, UAW v. OSHA, 37 F. 3d 665, 669 (D.C. Cir. 1994). 
rulemaking. Such a construction would limit only the upper end of the agency's range of discretion. Thus, if its adoption by EPA had any effect at all, it would require EPA to adopt a standard of 0.07 ppm or lower. A 0.07 standard would be much more costly than a 0.08 standard. It would require complete cessation of all industrial and transportation activities in some areas during some periods of time $^{139}$-- partial deindustrialization of the United States. Are two conservative Republican judges really trying to force the Clinton Administration to adopt a construction of CAA that requires both President Clinton and all of his successors to impose far more costly air quality rules? I doubt it, but this is a good point to repeat the old cliche: "Be careful what you ask for. You might get it." Hypothetical future President Al Gore might welcome the opportunity to say that he was compelled by the order of two Republican judges to issue more costly air quality rules. Conversely, hypothetical future President George W. Bush would find it hard to live with a construction of the CAA adopted by the Clinton Administration, under compulsion of an order issued by two Republican judges, that requires him to issue rules that are far more costly than he would prefer.

\section{The "Generic Unit of Harm" Criterion}

The ATA majority went on to suggest that EPA might adopt a "generic unit of harm" criterion "that takes into account population affected, severity [of harm], and probability [of harm]."140 For this purpose, the majority suggested that EPA might adopt "the approach Oregon used in devising its health plan for the poor."'141 Oregon attached values to various health states by polling a sample of citizens.

139 See note 41 supra.

140175 F. 3d at 1039.

141 Id. at 1039. 
As the ATA majority noted, however, the Department of Health and Human Services concluded that the Oregon approach violated the Americans with Disabilities Act (ADA). ${ }^{142}$ The ATA majority suggested that EPA could avoid this problem by relying in part on a poll of asthmatics to determine the values they place on the various states of pulmonary health that correllate with exposure to various concentrations of ozone and particulates. ${ }^{143}$

At bottom, this suggested construction would require EPA to use a peculiar version of a cba. The new version of a cba would differ from a traditional cba in three significant ways. First, it would require much more time and person-hours to implement, because it would require analysts to value more health benefits, e.g., non-fatal pulmonary distress, hospitalization, etc. ${ }^{144}$ Second, it would yield a much higher range of estimated benefits of a rule that reduces permissible ozone and particulate concentrations, both because it would place explicit values on more adverse health effects and because it would reflect the higher values of the most sensitive subset of the population. Third, it would not include any discussion or consideration of costs, in order to avoid violation of the D.C. Circuit's prior holding that EPA cannot consider costs in implementing section 109(b).

Like the ATA majority's other suggestions, it is impossible to take the "generic unit of harm" suggestion seriously. Its flaws are obvious. It would just provide a different method of describing the situation that EPA has already found to exist. EPA has estimated a variety of adverse health effects of varying levels of ozone exposure, e.g., deaths, hospitalizations, and incidents of non fatal pulmonary

142 Id. at 1039 note 5.

143 Id. at 1039 note 5.

144 EPA did not monetize many of the benefits of the new standards. RIA at ES-3. 
distress. The court urges EPA to translate each health effect into a common unit of measure, e.g., one death equals four hospitalizations or eight non fatal incidents of respiratory distress. It is hard to see any benefit from such an exercise. It is simply another symptom of the science charade -- requiring the illusion of objectivity and quantitative precision in a context in which science is incapable of providing either.

The resulting estimates of generic units of harm at various exposure levels would be worthless as a means of deciding "how much is too much." The generic unit of harm table would show exactly the same relationship between concentration and adverse health effects that EPA has already found to exist. The best data available suggest the existence of a "continuum," with no clear break points and no thresholds below which no risks to human health exist. ${ }^{145}$ The generic unit of harm table would show that same continuum. The table would have to be compared with something else to determine "how much is too much." The only logical comparative frame of reference is cost. Yet, the courts have held that EPA cannot consider cost. Finally, even if EPA could identify some legally-permissible comparative frame of reference -- perhaps some cleverly disguised surrogate for cost -- the result would not comply with the court's mandate. No matter how cleverly it is disguised or how its results are stated, cba cannot be a "determinate, binding standard." It is premised on a series of highly subjective value judgments and it is subject to massive indeterminacy. ${ }^{146}$

\section{THE COURT'S REMEDY IS ANTIDEMOCRATIC}

The ATA majority was motivated by a concern that has been voiced by many respected jurists

145 See sources cited in notes 39 and 65 supra.

146 See text at notes 93-128 supra. 
and academic commentators. Broad statutory delegations of power to agencies allow "politically unresponsive administrators" to make "fundamental policy decisions" that should be made only by elected officials. ${ }^{147}$ Many people have characterized this phenomenon as a major flaw in our system of constitutional democracy. ${ }^{148}$ For reasons that I will explain in part VI, I do not share that concern.

I do see, however, two major flaws in our system of constitutional democracy that would be created by the ATA majority's attempt to correct what it perceives to be a fatal flaw. The first flaw is obvious and immediate. Two unelected, life-tenured judges have decided that the United States should forego the opportunity to save about 10,000 lives per year in order to save about fifty billion dollars per year. Judges are the least politically accountable officials. They are the worst possible choice of officials to make such fundamental policy decisions in our system of constitutional democracy. ${ }^{149}$

The second unconstitutional and antidemocratic effect of the decision of the ATA majority is less direct and more subtle, but it is equally disturbing. As I understand the D.C. Circuit's 1991, 1994, and 1999 opinions, an agency can save its statute from a holding of unconstitutionality only by adopting a construction of its statute that binds the agency forever. If my interpretation is incorrect, the opinions are incoherent and meaningless. If an agency remains free to change its construction of the statute in the future, the court has had no effect whatsoever on the agency's degree of discretion or on the ability of reviewing courts to limit agency exercises of discretion. Under that interpretation, the D.C. Circuit has

147 See Benzene, 448 U.S. at 686-687. (Rehnquist, J., concurring.)

148 See, e.g., John Ely, Democracy and Distrust 132-134 (1980); James Freedman, Crisis and Legitimacy: The Administrative Process and American Government 93-94 (1978); Theodore Lowi, The End of Liberalism: The Second Republic of the United States 93 (1969).

149 See Chevron v. NRDC, 467 U.S. 837, 865-866 (1984). 
simply used the nondelegation doctrine as a bizarre vehicle to restate the pre-existing legal regime announced in cases like Chevron v. NRDC..$^{150}$

If my interpretation is correct, the court is ordering President Clinton to make a fundamental policy decision that will bind all of his successors. Such a legal regime would create a real problem for our system of constitutional democracy. Its effects would include reducing significantly the incentive to vote in Presidential elections. In the 2000 election, it is a safe bet that we will have a choice between a Democrat candidate who promises to increase the degree of protection provided by environmental rules and a Republican candidate who promises to reduce the costs of government regulation. Millions of people will have the opportunity to vote their preferences with respect to the critical issue that the ATA majority characterizes as "how much is too much."

Yet, if the legal regime created by the ATA majority is accepted as a permanent feature of our legal system, the voters who comprise a majority in that election will be frustrated to discover that their vote had no effect on any "fundamental policy decision." If hypothetical future President Gore is elected, he will be powerless to increase the degree of environmental protection provided by EPA rules. If hypothetical future President Bush is elected, he will be powerless to decrease the costs of

150467 U.S. 837. See Davis \& Pierce, supra. note 19, at 3.5. Some commentors on a draft of this paper suggested a third plausible interpretation of the ATA opinion. They suggested that a newly-elected President could use a two-step decisionmaking process. Under this approach, EPA would first conduct a meta rulemaking in which it announces its construction of section 109(b), e.g., section 109(b) requires maximization of public health benefits short of deindustrialization. If a court upholds that construction, EPA would then conduct rulemakings to set new section 109(b) standards through application of that construction of the statute. That interpretation of the opinion raises a host of problems, however. For starters, no President would have any hope of completing the process during his term of office. 
environmental regulation. I would have to reconsider my decision whether to vote in presidential elections in such a dramatically transformed political system. Why bother to vote for a new President if the courts will require him to adhere to all of the major policy decisions of one of his predecessors? I would also be much less comfortable living in such a political system. Our system of government would be much less accountable to the people if all fundamental policy decisions had to be made either by unelected, life-tenured judges or by Presidents who can bind their predecessors for decades.

\section{BROAD DELEGATIONS OF POWER ARE NOT A THREAT TO CONSTITUTIONAL DEMOCRACY}

In this part, I will explain why I do not share the belief of the ATA majority that broad delegations of policy making discretion to agencies violate the Constitution and represent a serious flaw in our system of democracy. The answer is simple. "Fundamental policy decisions," like the EPA's ozone and particulate decisions, are not made by "politically unresponsive administrators," except in the most narrow, naive, and formalistic sense. The EPA Administrator is chosen by the President and serves at the pleasure of the President. A President cannot "overrule" or "displace" a decision of the Administrator, but a President can engage in what the D.C. Circuit has characterized as "jawboning" or "arm twisting" in an attempt to persuade the Administrator to act in a manner consistent with the

President's preferences. ${ }^{151}$ There is ample reason to believe that Presidents routinely engage in that practice when an agency makes a "fundamental policy decision" and ample reason to believe that

151 See Sierra Club v. Costle, 657 F. 2d 298, 400-410 (D.C. Cir. 1978). 
Presidential jawboning is invariably successful in that context. ${ }^{152}$ Thus, it is far more accurate to attribute these decisions to the President, as the Supreme Court did in Chevron. ${ }^{153}$ Moreover, the judicially-imposed prohibition on EPA's consideration of costs in setting air quality standards does not apply to the President. He can, and undoubtedly does, consider costs and benefits in determining his preferences and, hence, the action he urges the Administrator to take. ${ }^{154}$

The standard Congress included in section 109(b) is far more determinate than the standards it often employs in statutes that delegate power to agencies. ${ }^{155}$ I have attempted to demonstrate both in this article and elsewhere that it is absurd to expect Congress to make the types of decisions that EPA made in the ozone and particulate rulemakings, and that it would be destructive in many ways to demand that Congress make all decisions of this type. ${ }^{156}$ In cases where Congress was able to respond to such a demand by making a decision, we would get terrible congressional decisions. ${ }^{157}$ In cases where Congress was unable to comply with such a demand, we would get judicial resolutions of fundamental policy decisions by default. If I am right, we are left with limited choices. First, we could assign the discretion to make fundamental policy decisions to judges. That is one potential result of the

152 See Davis \& Pierce, supra. note 19 , at $§ \$ 2.6 \& 7.9$; Wagner, supra. note 4 , at 1641 1644.

153467 U.S. at 865-866.

154 See Wagner, note 4, at 1641-1644.

155 See text at notes 14 to 21 supra.

156 See, e.g., Pierce, supra. note 90; Richard Pierce, Political Accountability and Delegated Power: A Response to Professor Lowi, 36 Am. U. L. Rev. 391 (1987).

157 See note 92 supra. 
decision in ATA. Second, we could force the incumbent President to make a fundamental policy decision that binds his predecessors in perpetuity. That is the other potential result of the decision in ATA. Third, we could assign that discretion to each President, as the Supreme Court held that we must in Chevron. I find that choice incredibly easy. In our system of constitutional democracy, Presidential elections matter. If a majority of the electorate disapproves of how the incumbent President decides "how much is too much," they will elect a new President who will draw the line either higher or lower than the incumbent. That is not a threat to democracy. That is democracy. The Supreme Court described the principles that apply to such policy disputes in its unanimous opinion in

\section{Chevron:}

While agencies are not directly accountable to the people, the Chief Executive is and it is entirely appropriate for this politically accountable branch of the Government to make such policy choices -- resolving the competing interests which Congress . . . left to be resolved by the agency charged with the administration of the statute in light of everyday realities. ${ }^{158}$

158467 U.S. at 865-866. 